Наносистели, нанолатеріали, нанотехнології Nanosistemi, Nanomateriali, Nanotehnologii 2018, т. 16, № 2, сc. 389-401 (c) 2018 ІМФ (Інститут металофізики ім. Г. В. Курдюмова НАН України) Надруковано в Україні. Фотокопіювання дозволено тільки відповідно до ліцензії

PACS numbers: 31.15.-p, 31.50.-x, 33.15.-e, 33.70.-w, 36.20.-r, 61.48.-c, 81.05.ub

\title{
Quantum-Chemical Study of Acceptor Properties of Fullerene and Its Bridge Derivatives
}

\author{
E. L. Pavlenko ${ }^{1}$, V. A. Sendiuk ${ }^{1}$, V. A. Brusentsov ${ }^{1}$, O. P. Dmytrenko ${ }^{1}$, \\ M. P. Kulish ${ }^{1}$, N. V. Obernihina ${ }^{2}$, Y. O. Prostota ${ }^{3}$, O. D. Kachkovsky ${ }^{3}$, \\ and V.S. Brovarets ${ }^{3}$
}

${ }^{1}$ Taras Shevchenko National University of Kyiv,

Faculty of Physics,

64/13, Volodymyrs'ka Str.,

UA-01601 Kyiv, Ukraine

${ }^{2}$ O. O. Bogomolets National Medical University,

34, Peremogy Ave.,

UA-03055 Kyiv, Ukraine

${ }^{3}$ Institute of Bioorganic Chemistry and Petrochemistry, N.A.S. of Ukraine,

1, Murmans'ka Str.,

UA-02660 Kyiv, Ukraine

The quantum-chemical study of the 1- and 2-dimensional conjugated hydrocarbon systems with ordinary $s p^{2}$-hybridization of the carbons (polyenes and acenes) is performed. The analysis shows that the energies of frontier levels depend directly on the extending of the $\pi$-system, but the energy-gap middle remains practically the same and corresponds to the energy of the initial $2 p_{z}$-electrons forming the collective system of $\pi$ electrons. The shift of the energy-gap middle in any conjugated molecule in respect to the standard polyenic or aromatic system can be connected to the donor-acceptor property. For its quantitative estimation, the topological index $\varphi_{0}$ is proposed. Going to non-aromatic compounds as well as to concave conjugated-surfaces' shifts, the energy gap downs and hence decreases the topological index $\varphi_{0}$. Therefore, the fullerene with its spherical constitution is proven as a strong acceptor. Introducing a carbon bridge to the fullerene molecule with two $s p^{3}$-hybridized carbons can increase the parameter $\varphi_{0}$ and decrease its acceptor strength.

Проведено квантово-хемічне дослідження 1- та 2-вимірних спряжених вуглеводневих систем із звичайною $s p^{2}$-гібридизацією атомів Карбону (поліенів та аценів). Аналіза показує, що енергії суміжних рівнів напряму залежать від протяжности $\pi$-системи, але середня енергетична щілина залишається практично однаковою та відповідає енергії початкових $2 p_{z}$-електронів, що утворюють колективну систему $\pi$-електронів. 
Зсув середини енергетичної щілини в любій спряженій молекулі щодо стандартної поліенової або ароматичної системи може бути зв'язаний із донорно-акцепторною властивістю. Для його кількісного оцінювання пропонується топологічний індекс $\varphi_{0}$. Переходячи до неароматичних сполук, а також до вгнутих спряжених поверхневих зміщень, енергетична щілина спадає $\mathrm{i}$, отже, зменшує топологічний індекс $\varphi_{0}$. Тому фуллерен 3 його сферичною будовою доведений як сильний акцептор. Введення вуглецевого містка у молекулу фуллерена 3 двома $s p^{3}$. гібридизованими атомами Карбону може збільшити параметер $\varphi_{0}$ i зменшити його акцепторну міцність.

Проведено квантово-химическое исследование 1- и 2-мерных сопряжённых углеводородных систем с обычной $s p^{2}$-гибридизацией атомов углерода (полиенов и аценов). Анализ показывает, что энергии пограничных уровней напрямую зависят от протяжённости $\pi$-системы, но средняя энергетическая щель остаётся практически одинаковой и соответствует энергии начальных $2 p_{z}$-электронов, образующих коллективную систему $\pi$-электронов. Сдвиг середины энергетической щели в любой сопряжённой молекуле по отношению к стандартной полиеновой или ароматической системе может быть связан с донорно-акцепторным свойством. Для его количественной оценки предлагается топологический индекс $\varphi_{0}$. Переходя к неароматическим соединениям, а также к вогнутым сопряжённым поверхностным смещениям, энергетическая щель спадает и, следовательно, уменьшает топологический индекс $\varphi_{0}$. Поэтому фуллерен с его сферическим строением доказан как сильный акцептор. Введение углеродного мостика в молекулу фуллерена с двумя $s p^{3}$-гибридизованными атомами углерода может увеличить параметр $\varphi_{0}$ и уменьшить его акцепторную прочность.

Key words: fullerene and its bridge derivatives, planar and concave conjugated surfaces, quantum-chemical calculations, energy gap, topological index $\varphi_{0}$.

Ключові слова: фуллерен та його місткові похідні, пласкі та вгнуті спряжені поверхні, квантово-хемічні розрахунки, енергетична щілина, топологічний індекс $\varphi_{0}$.

Ключевые слова: фуллерен и его мостиковые производные, плоские и вогнутые сопряжённые поверхности, квантово-химические расчёты, энергетическая щель, топологический индекс $\varphi_{0}$.

(Received 23 April, 2018)

\section{INTRODUCTION}

The $\mathrm{C}_{60}$ fullerene, which is a 2-dimensional spherical conjugated system, has attracted a great deal of interest due to its unique structure and properties [1]. The molecule $\mathrm{C}_{60}$ has high symmetry 
and stability, and is unique among experimentally available 2dimensional carbon compounds with a branched $\pi$-electron shell. Among the properties of fullerenes determined by electronic structure and symmetry, there are the optical properties having potential applications, for example, the production of fullerene-based optical limiters [2]. The optical properties of fullerene $\mathrm{C}_{60}$ and its related compound $\mathrm{C}_{70}$ were considered in detail in review [3]; the electronic spectroscopy studies were carried out in solutions, noble gas matrices or in the gas phase, where the properties of approximately isolated molecules can be monitored. Obtained spectroscopic data were comparable with the results of quantum-chemical calculations performed for the isolated fullerene molecules [4], enabling a reliable interpretation of the experimental data.

Fullerenes were often applied in the composite with other conjugated molecules, for examples, polyenes [5], polymethine dyes, etc. [6-8]. In such composites, the effective stack interaction between two conjugated components should occur. Regarding the interaction of $\mathrm{C}_{60}$ with other conjugated systems, it is assumed that the fullerene $\pi$-system is simultaneously both a good electron donor due to rather low ionization potential and a good electron acceptor due to extremely high electron affinity; so, in any $\mathrm{C}_{60}$, pair donor-acceptor (DA) interaction should be significant [9]. For example, fullerenes can be electron acceptors in the solar cells [5].

A clear understanding of DA processes occurring in fullerenebased binary systems demands the correct investigation of the donor/acceptor properties of the fullerene and its derivatives, including the quantum-chemical study. Similar, quantum-chemical modelling was carried out in paper [10], where the neutral squaraine dye molecule was used as a donor. The stack interaction of any two conjugated compounds should depend on the mutual disposition of the frontier levels (or energy gap) of the donor and the acceptor (i.e. fullerene). This mutual disposition of frontier levels (or energy gap) is directly connected with the donor/acceptor of both the conjugated component and the fullerene molecule.

Fullerenes can be used as photosensitizers in photodynamic therapy by being chemically bonded with various conjugated molecules through an unsaturated bridge; the quantum-chemical firstprinciples study was proposed in the work [4]. The modification of the fullerene's chemical constitution upon the introduction of a hydrocarbon bridge and hence upon the change of hybridization of two carbon atoms should be accompanied by a change of the donor/acceptor properties of the modified fullerene derivatives.

This paper deals with the studies of the energy gap disposition in the fullerene as well as its derivatives with $s p^{3}$-hybridized atoms (used in solar cells) relative to gap middle of a standard conjugated 
system (polyenes or acenes), in which the donor and acceptor properties are mutually balanced.

\section{POSITIONS OF FRONTIER LEVELS IN 1- AND 2-DIMENSIONAL CONJUGATED SYSTEMS}

Let us consider the relative positions of frontier levels and, hence, the energy gap in the simplest conjugated systems. The parity theorem states that all $\pi$-electron levels are disposed asymmetrically relative the non-bonding levels and hence any level can be given by the next formulas: $\varepsilon_{i}=\alpha \pm x_{i} \beta$, where $\alpha$ is a Coulomb integral, $\beta$ is a resonance integral; the plus sign corresponds to the occupied levels while the minus sign corresponds to the vacant levels [11]. Schematically, this theorem is presented in Fig. 1.

The positions of frontier levels and the distance between them (the energy gap) depend on the chemical constitutions of conjugated molecule. The simplest example of a regular change in $\pi$-electron system dimension can be a vinylogous series of the ordinary 1dimensional polyenes 1 and simplest 2-dimensional acenes 2, pic-

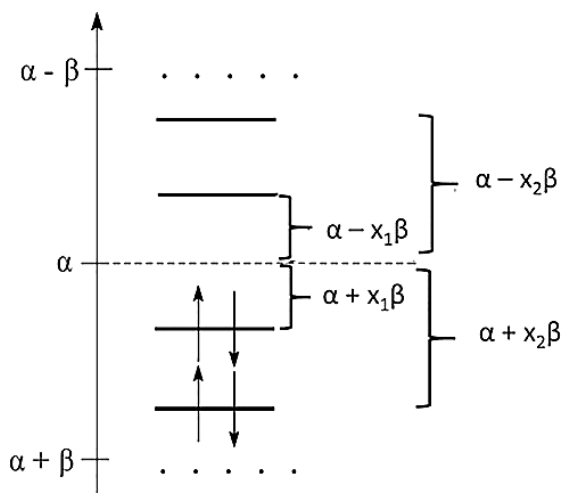

Fig. 1. Parity theorem for neutral conjugated systems: occupied and vacant levels are situated symmetrically relative to Coulomb integral energy $\alpha$.

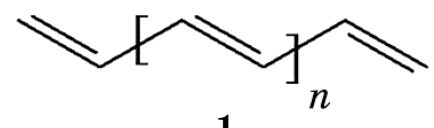

1

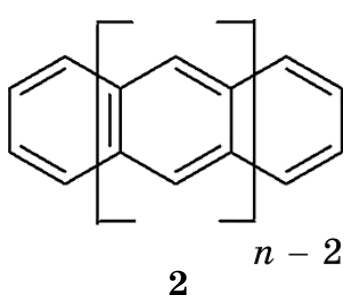

2

Fig. 2. Chemical formulas of polyenes $\mathbf{1}$ and polyacenes $\mathbf{2}$. 
tured in Fig. 2. Calculations are performed by HF and DFT/6-31 $(d, p)$ methods (with different functionals) using Gaussian 03 software [12].

Figure 3 presents the energies of frontier levels and positions of energy gap middle, $\varepsilon_{1 / 2}=\left(\varepsilon_{\text {Номо }}+\varepsilon_{\mathrm{LUMO}}\right) / 2$, for each member of both series 1 and $2(n=2-10)$, calculated by the HF method.

The lengthening of both polyene and acene chain causes a regular increase of the energy of the HOMO and simultaneously a decrease of the energy of the LUMO, however the gap middle, $\varepsilon_{1 / 2}$, remains virtually constant, i.e., this one corresponds to parity theorem. Besides, the parameters $\varepsilon_{1 / 2}$ calculated for the polyenes 1 and acenes 2 are in close agreement. The same tendency is confirmed by calculations in higher approximations, for example, by the HF method or by DFT methods explicitly taking into account electron correlations.

It was noticed above that the donor and acceptor properties in the series $\mathbf{1}$ and $\mathbf{2}$ are balanced, and their gap middle is constant, independently of the chain length $n$. This gap middle energy corresponds to the non-bonding level energy or to Coulomb integral $\alpha$. This means, we can refer to the relative positions of the frontier levels in the compounds $\mathbf{1}$ and $\mathbf{2}$ as to standard conjugated systems. On the other hand, we could state that shift of the gap middle up or down relative to the value $\alpha$ should indicate the growth of donor or acceptor ability, correspondingly.

For the quantitative estimation of the donor/acceptor ability of any conjugated molecules, a special index $\varphi_{0}$ was proposed earlier $[13,14]$. This parameter describes the relative position of energy gap; it can be calculated quantum-chemically by the following formula:

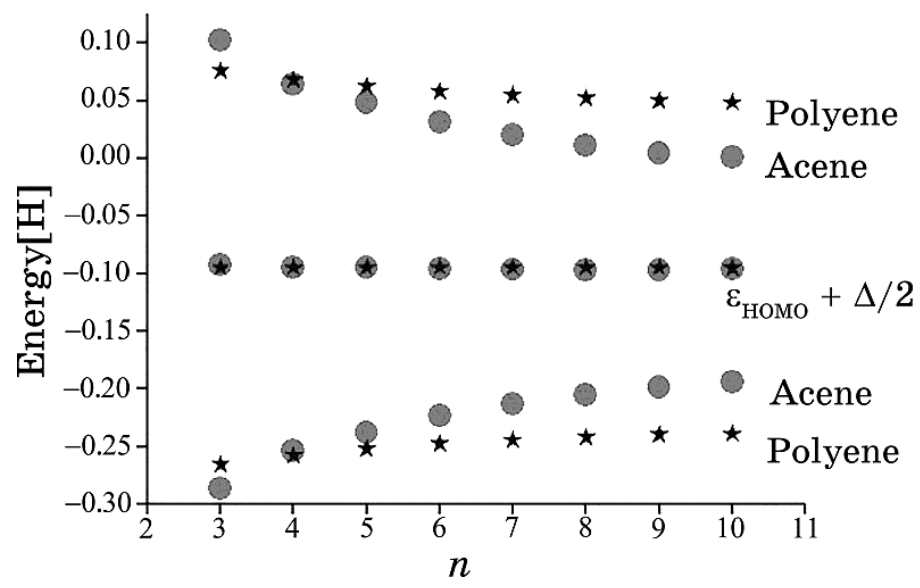

Fig. 3. Energies of frontier levels and energy gap middle, $\varepsilon_{1 / 2}$, in series 1, 2. 


$$
\varphi_{0}=\frac{\varepsilon_{\mathrm{LUMO}}-\alpha}{\varepsilon_{\mathrm{LUMO}}-\varepsilon_{\text {HоMо }}} .
$$

For polyenes and acenes, the index $\varphi_{0}=S$, i.e., the energy gap is located symmetrically in respect to the imaginary level $\alpha$. The calculation (by $\mathrm{HF}$ method) of a comparatively long polyene, $\mathrm{C}_{12} \mathrm{H}_{24}$, gives $\varepsilon_{\mathrm{LUMO}}=-1.296 \mathrm{eV}, \varepsilon_{\text {номо }}=-5.747 \mathrm{eV}$, and $\alpha=-3.524 \mathrm{eV}$; consequently, $\varphi_{0}=0.5$. Similarly, for the long acene chain, $n=8$, index $\varphi_{0}=0.5$. Thus, in these molecules, both donor and acceptor properties are mutually balanced (and hence $\varphi_{0}=0.5$ ) as schematically pictured in Fig. 4, a.

An upwards shift of the energy gap up, and, hence, an increase

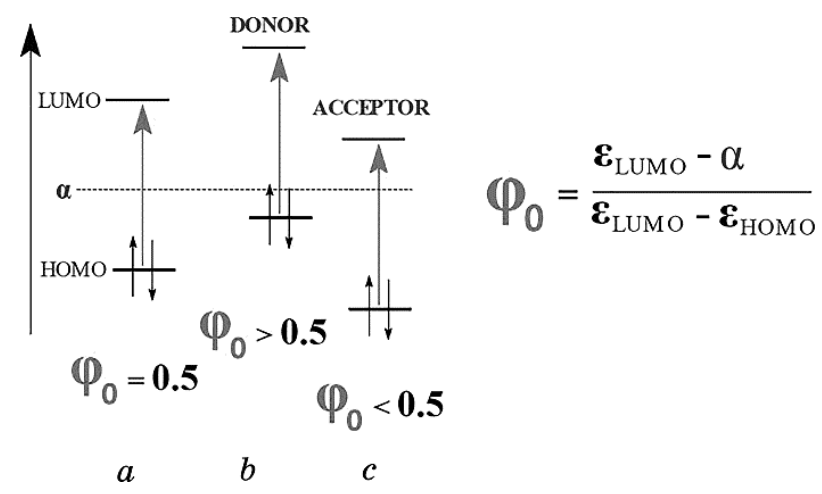

Fig. 4. Relative positions of frontier levels in the balanced (a), donor (b) and acceptor $(c)$ system.

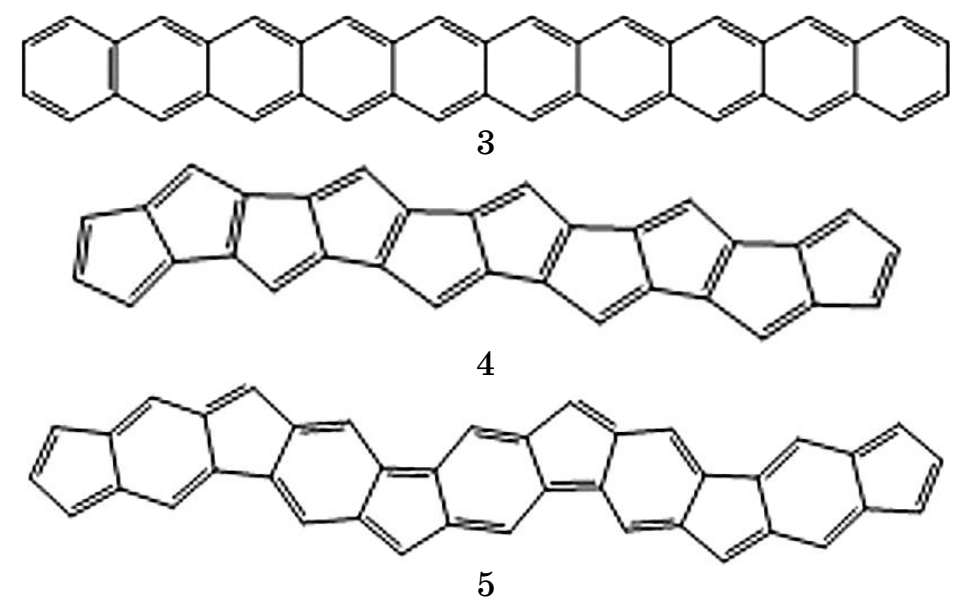

Fig. 5. Chemical formulas for three model planar conjugated systems. 
of the parameter $\varphi_{0}>0.5$ indicates the predominately donor properties of the conjugated molecules, as demonstrated in Fig. 4, $b$. If the parameter $\varphi_{0}<0.5$ and the energy are shifted down, then the molecule is predominately acceptor (Fig. 4, c).

Before we go to the fullerene molecule and its derivatives, let us consider the relative position of the energy gap in some model 2dimensional surfaces with branched conjugated systems.

\section{PLANAR 2-DIMENTSIONAL $\pi$-ELECTRON MOLECULES}

Here, we will compare donor/acceptor parameters for the three main linear conjugated ribbons constructed from 6, 5 cycles and their combination, correspondingly: $3,4,5$, chemically presented in Fig. 5.

The energies of their frontier levels and the indices $\varphi_{0}$ of the molecules 3-5 calculated in three approximations are collected in Table 1. As a standard molecule, we will instate the long polyene 1 at $n=8$.

Firstly, it has to be noticed that the energies of the non-bonding orbital $\alpha$ depend on the used quantum-chemical approximation; so, taking into consideration the electron correlation in both DFT methods decreases slightly MO energies, although one can see from Table 1 that the sensitivities of the HOMO and LUMO are different.

Analysis shows that the calculated index $\varphi_{0}$ for the 6-membered acene 3 coincides practically with that for the standard polyene 1 ,

TABLE 1. MO energies and index $\varphi_{0}$ for acenes $3-5$ and polyene $\mathbf{1}, n=8$.

\begin{tabular}{cccccc} 
Molecule & Method & $\varepsilon_{\text {Hомо }}$, a.u. & $\varepsilon_{\text {LUMO }}$, a.u. & $\Delta$, a.u. & $\varphi_{0}$ \\
\hline 3 & HF & -0.18498 & -0.01167 & 0.17331 & 0.477 \\
& CAM & -0.19121 & -0.07111 & 0.1201 & 0.486 \\
\multirow{4}{4}{} & wB & -0.20745 & -0.05961 & 0.14784 & 0.518 \\
& HF & -0.22942 & 0.01489 & 0.24431 & 0.447 \\
& CAM & -0.21067 & -0.06992 & 0.14075 & 0.423 \\
5 & wB & -0.22525 & -0.06051 & 0.16474 & 0.427 \\
& HF & -0.23758 & 0.00624 & 0.24382 & 0.412 \\
& CAM & -0.22206 & -0.07216 & 0.1499 & 0.382 \\
$\mathbf{1}, n=8$ & wB & -0.23700 & -0.06338 & 0.17362 & 0.388 \\
& HF & -0.23764 & 0.04910 & 0.28674 & 0.5 \\
& CAM & -0.21120 & -0.04766 & 0.16354 & 0.5 \\
& wB & -0.23116 & -0.03046 & 0.2007 & 0.5 \\
\hline
\end{tabular}

Remarks: $\Delta=\varepsilon_{\mathrm{LUMO}}-\varepsilon_{\mathrm{HOMO}} ; \alpha(\mathrm{HF})=-0.09427$ a.u.; $\alpha(\mathrm{CAM})=-0.12943$ a.u.; $\alpha(\mathrm{wB})=-0.1308$ a.u.; CAM-DFT/CAM-B3LYP; wB-DFT/wB97XD. 
which agrees with the above statement that the donor and acceptor abilities in both series, 1 and 3 , are practically balanced. In contrast to the simplest acene 3 constructed from benzene cycles by their anellation, the acceptor strength of both other planar 2-dimensional surfaces 4 and 5 (Table 1) increases, as the parameter $\varphi_{0}$ decreases. The molecule 5 contains the series of alternating 5 - and 6 -membered cycles; its index $\varphi_{0}$ is minimum among the planar 2-dimensional conjugated systems.

\section{CONCAVE 2-DIMENTSIONAL $\pi$-ELECTRON MOLECULES}

Now, we will consider the concave surfaces, in which the $s p^{2}$ hybridization is not total, similarly to fullerene. Four examples of finite concave surfaces are presented in Fig. 6, $b-e$. Besides, Figure 6 , $a$ shows the cylindrical acene 6 , which corresponds to the linear acene $3, n=8$, self-contained in the simplest cylinder (without any chirality).
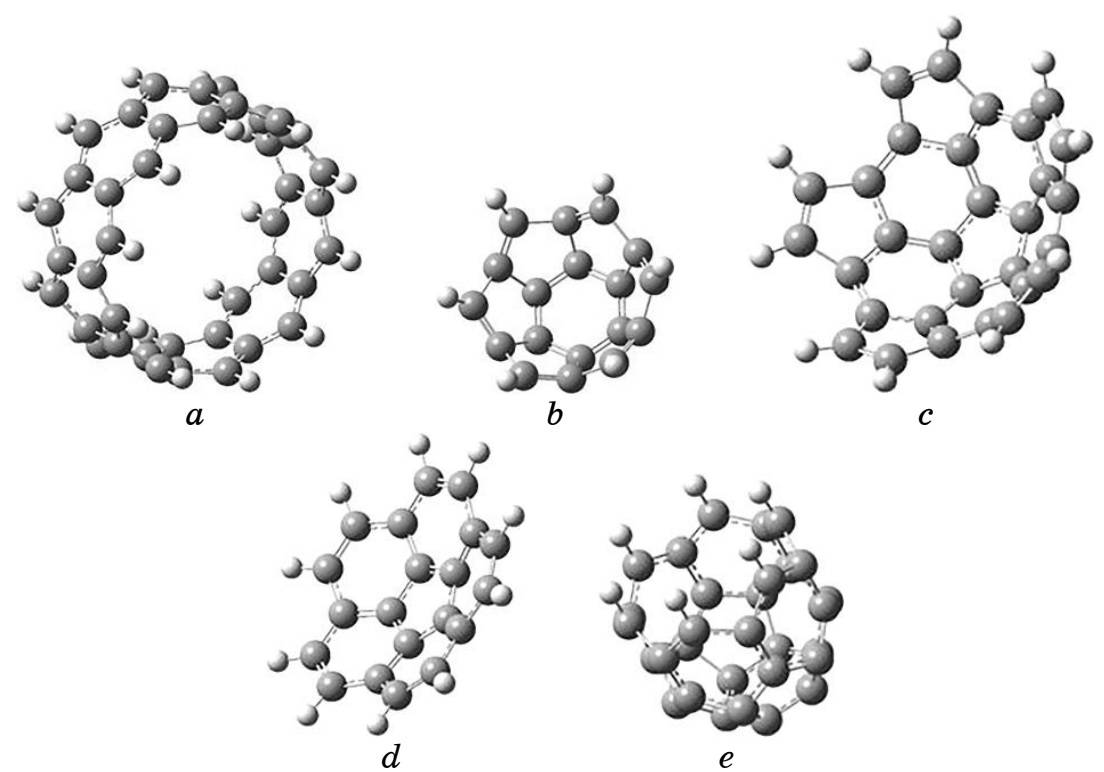

Fig. 6. Formulae of concave conjugated 2-dimensional systems: 6, 7, 8, 9, 10. Other model molecules contain 2 or 3 layers of annellated cyclic conjugated systems. $b$-the molecule 7 contains 2 layers: the 1 -st layer contains the 6-membered cycle, the 2-nd layer contains six 5-membered cycles; $c-$ in the molecule 8, a third layer with six 5-membered cycles is added; $d-$ the molecule 9 contains 2 layers: the 1-st layer is the 5-membered cycle; the 2-nd layer contains five 6-membered cycles; $e$-the molecule 10 contains additionally the third layer with six 6 -membered cycles. 
Thus, these 2-dimensional concave surfaces could be considered as any pieces or fragments of the fullerenes $\mathrm{C}_{60}$ or $\mathrm{C}_{70}$.

The calculated donor/acceptor indices of the compounds 6-10 are collected in Table 2, which is similar to the previous Table 1.

In spite of the sizeable differences in the positions of frontier levels and energy gaps obtained for different types of the concave surfaces, their donor/acceptor indices are close enough to the middle value: 0.5 . Nevertheless, the surfaces are appreciably sensitive to different types of bending. Therefore, rolling the long acene chain 3 into the cylinder 6 practically does not affect the parameter $\varphi_{0}: 0.477 \rightarrow 0.476$ (HF method). The other methods taking into account electron correlations show the same tendency.

The formation of a concave surface causes changes in the donor/acceptor properties that are more essential. Table 2 shows that the index $\varphi_{0}$ depends on the first (initial or basing) cycle (6- or 5membered) and the cycle type of the next layers. It is established that the electron-excessive 5-membered cycles leads to increasing of the donor ability $\left(\varphi_{0}>0.5\right)$, while benzene 6 -membered cycles decreases the parameter $\varphi_{0}<0.5$. In addition, the third layer from the 6 -membered cycles in model molecule 8 decreases the index $\varphi_{0}$, whereas the third layer from the 5-membered cycles (model conjugated 10) increases this parameter.

Thus, the donor/acceptor properties of the concave conjugated surfaces depend on the chemical constitution of conjugated frag-

TABLE 2. MO energies and indices $\varphi_{0}$ for concave surfaces 6-10.

\begin{tabular}{cccccc}
\hline Molecule & Method & $\varepsilon_{\text {Hомо }}$, a.u. & $\varepsilon_{\text {LUMO }}$, a.u. & $\Delta$, a.u. & $\varphi_{0}$ \\
\hline $\mathbf{6}$ & HF & -0.1563 & -0.026 & 0.13038 & -0.476 \\
& CAM & -0.162 & -0.0899 & 0.07218 & -0.452 \\
7 & wB & -0.177 & -0.0805 & 0.09648 & -0.479 \\
& HF & -0.2481 & 0.04246 & 0.29054 & -0.529 \\
& CAM & -0.2267 & -0.048 & 0.17868 & -0.544 \\
$\mathbf{8}$ & wB & -0.245 & -0.0353 & 0.20969 & -0.544 \\
& HF & -0.2094 & 0.00124 & 0.21064 & -0.396 \\
& CAM & -0.1986 & -0.0822 & 0.11641 & -0.387 \\
$\mathbf{9}$ & wB & -0.2222 & -0.0635 & 0.15867 & -0.436 \\
& HF & -0.293 & 0.07246 & 0.3655 & -0.544 \\
& CAM & -0.2714 & -0.0119 & 0.25948 & -0.547 \\
$\mathbf{1 0}$ & wB & -0.2926 & 0.00385 & 0.29648 & -0.546 \\
& HF & -0.2702 & 0.03658 & 0.30682 & -0.574 \\
& CAM & -0.2513 & -0.0456 & 0.20569 & -0.592 \\
& wB & -0.2719 & -0.0323 & 0.23965 & -0.589 \\
\hline
\end{tabular}


ments. One could propose that the transformation of conjugated surfaces (or flatland) should influence the stack interaction between such surfaces and any conjugated heterocycles.

\section{FULLERENE AND ITS $s p^{3}$-HYBRIDIZED DERIVATIVES}

Here, we will consider the relative position of the energy gap in the fullerene $1(a)$ and four of its simplest derivatives 11-15 with two $s p^{3}$-hybridzed carbon atoms and hence with a complicated bridge, pictured in Fig. 7. Usually, the various conjugated molecules can be used in the substituted composite 15 instead of the model methyl

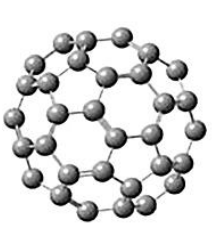

$a$

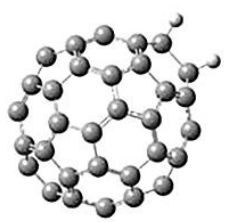

$b$

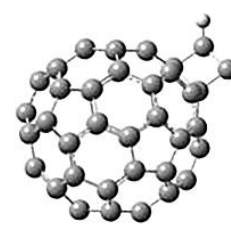

$c$
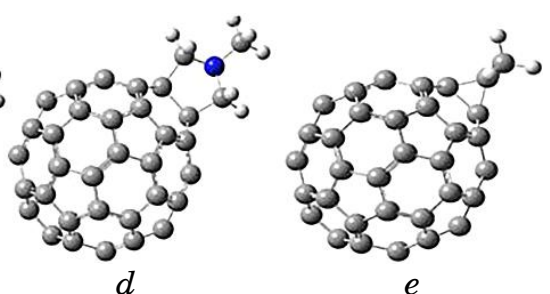

Fig. 7. Formulas of fullerene and its derivatives.

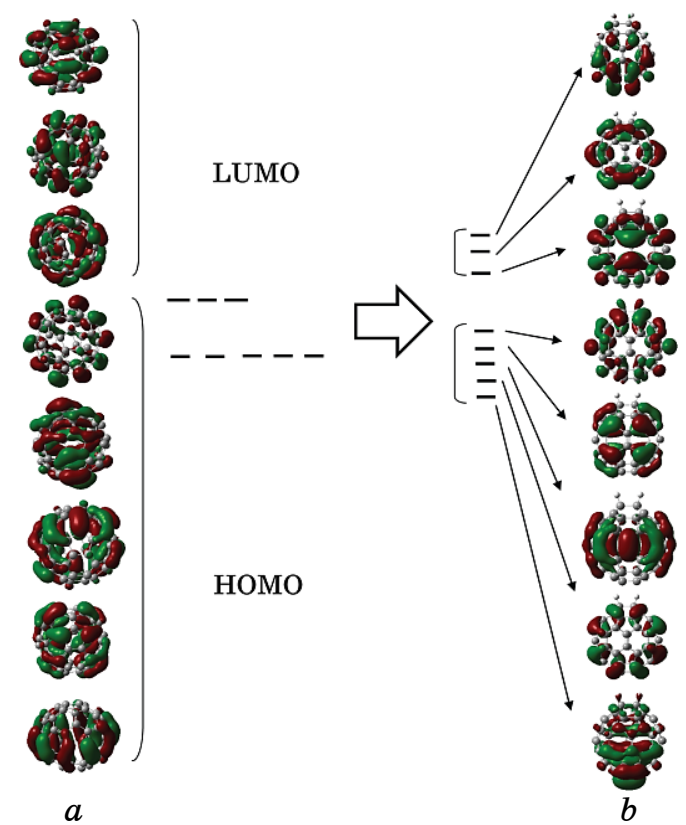

Fig. 8. Positions and shapes of some vacant and occupied MOs in fullerene $11(a)$ and $2 \mathrm{H}$-derivative. 
$\left(-\mathrm{CH}_{3}\right)$ group bonded with the nitrogen atom in the bridge.

It was established that the highest occupied level in the fullerene is quintuply degenerated, while the lowest vacant level is triply degenerated because of its symmetry, as visually pictured in Fig. 8, $a$.

The change of the hybridization of two carbon atoms in the fullerene derivatives causes the splitting of the degenerated level. The calculated splitting range for the frontier levels are collected in Table 3 .

The removal of two $\pi$-centres from the conjugated system upon going from the fullerene 11 to its derivatives $12-15$ is accompanied by changes in the shapes of frontier orbitals, as seen in Fig. 8, $b$.

The range of detectable level splitting for the highest level, $\delta(\mathrm{HOMO})$, is somewhat larger than for the vacant level, $\delta$ (LUMO), at $\approx 0.25 \mathrm{eV}$. The values $\delta$ are close for derivatives NN $(2 \mathrm{H}, 2 \mathrm{Me}$, Bridge), only for NN (Prop), the calculated splitting region is lesser. Besides, both DFT methods yield lower level splitting, than the HF method.

Because of this splitting of frontier levels, the energy gap in the molecules $12-15$ is proven to be shifted slightly in comparison with the initial fullerene 11. This necessarily leads to the change of acceptor property of the fullerene derivatives. The calculated indices for compounds 11-15 are presented in Table 4.

A careful analysis of calculated data shows that the frontier levels of the fullerene and its derivatives are sizeably shifted down, in comparison with the corresponding levels in 1- or 2-dimensional

TABLE 3. Splitting of the frontier MO degeneration in fullerene derivatives (in $\mathrm{eV}$ ).

\begin{tabular}{cccc}
\hline & Method & $\delta$ (HOMO) & $\delta$ (LUMO) \\
\hline FULL-2H & HF & 0.79 & 0.52 \\
FULL-2H & CAM & 0.67 & 0.42 \\
FULL-2H & wB & 0.68 & 0.43 \\
FULL-2ME & HF & 0.79 & 0.52 \\
FULL-2ME & CAM & 0.68 & 0.42 \\
FULL-2ME & wB & 0.69 & 0.43 \\
FULL-BRID & HF & 0.72 & 0.51 \\
FULL-BRID & CAM & 0.47 & 0.41 \\
FULL-BRID & wB & 0.47 & 0.42 \\
FULL-PROPIL & HF & 0.58 & 0.44 \\
FULL-PROPIL & CAM & 0.46 & 0.34 \\
FULL-PROPIL & wB & 0.45 & 0.34 \\
\hline
\end{tabular}

$\delta(\mathrm{HOMO})=\varepsilon_{\mathrm{HOMO}}-\varepsilon_{\mathrm{HOMO}-4} ; \delta(\mathrm{LUMO})=\varepsilon_{\mathrm{LUMO}+2}-\varepsilon_{\mathrm{LUMO}}$. 
TABLE 4. MO energies and index $\varphi_{0}$ for concave surfaces 1-15.

\begin{tabular}{cccccc}
\hline Molecule & Method & $\varepsilon_{\text {HOMO }}$ a.u. & $\varepsilon_{\text {LUMO }}$, a.u. & $\Delta$, a.u. & $\varphi_{0}$ \\
\hline 11 Fullerene & HF & -0.2813 & -0.0084 & 0.27284 & 0.315 \\
& CAM & -0.2645 & -0.0781 & 0.18639 & 0.275 \\
12 F-2H & wB & -0.2878 & -0.0658 & 0.22208 & 0.293 \\
& HF & -0.2691 & -0.0034 & 0.26574 & 0.342 \\
& CAM & -0.2501 & -0.0783 & 0.17181 & 0.297 \\
13 F-2Me & wB & -0.274 & -0.0624 & 0.21157 & 0.323 \\
& HF & -0.2659 & -0.0046 & 0.26128 & 0.343 \\
& CAM & -0.2502 & -0.0738 & 0.17634 & 0.315 \\
14 F-Pr & wB & -0.2726 & -0.0609 & 0.21166 & 0.33 \\
& HF & -0.2689 & -0.0065 & 0.26244 & 0.334 \\
& CAM & -0.2523 & -0.0787 & 0.17355 & 0.292 \\
15 F-Bridge & wB & -0.2762 & -0.0628 & 0.21341 & 0.319 \\
& HF & -0.2693 & -0.0033 & 0.26593 & 0.342 \\
& CAM & -0.2509 & -0.0778 & 0.17304 & 0.298 \\
& wB & -0.2745 & -0.0617 & 0.21277 & 0.325 \\
\hline
\end{tabular}

conjugated molecules with the same energy gap. So, the lowest vacant level is situated approximately $1.5 \mathrm{eV}$ lower than the corresponding level in polyene 1 at $n=10$ or in acene 3 at $n=6$, while the highest occupied one is shifted down on $1.1 \mathrm{eV}$. Such an inequivalent shifting of both frontier levels (upon close energy gaps) causes an appreciable change of the acceptor ability, so the parameter decreases essentially: from $\varphi_{0}=\mathbf{0 . 5}$ for the polyenes and acenes to $\varphi_{0} \approx 0.32-0.34$ for the fullerene per se and for its derivatives. The electron correlation, accounted for by the DFT methods, increases the acceptor ability between linear conjugated systems (1- or 2 -dimensional) with their total $s p^{2}$-hybridization of the carbon atoms and the spherical fullerene $\pi$-system with the distortion of the $s p^{2}$-hybridization.

Also, Table 4 shows that the change of the hybridization of two carbon atoms to the 'pure' $s p^{3}$-hybridization (chemically, to the protonation of two atoms) is accompanied by the increase of the index $\varphi_{0}$ for $\approx 0.17-0.19$ in fullerene derivatives that causes the inequivalent splitting of the degenerated LUMO and HOMO upon going from the fullerene 11 to its derivatives $12-15$.

Thus, the acceptor property of the spherical 2-dimensional conjugated molecules should exceed such characteristic of the linear systems (e.g., the graphene ribbons). The change of the acceptor strength can be quantitatively estimated by the proposed quantumchemical index $\varphi_{0}$ indicating the relative position of the energy gap. 


\section{CONCLUSION}

The analysis of the quantum-chemical study of the 1- and 2dimensional conjugated hydrocarbon systems with ordinary $s p^{2}$ hybridization of the carbons (polyenes and acenes) shows that the frontier level energies depend directly on the extension of the $\pi$ system, however, the energy gap middle remains practically the same, and corresponds to the energy of the initial $2 p_{z}$-electrons forming the collective system of $\pi$-electrons. The shift of the energy gap middle in any conjugated molecule in respect to the standard polyenic or aromatic system can be connected with the donoracceptor property; for its quantitative estimation, the index $\varphi_{0}$ is proposed. Going to non-aromatic compounds as well as to concave conjugated-surfaces' shifts, the energy gap downs and, hence, decreases the topological index $\varphi_{0}$. This way, the fullerene with its spherical constitution is proven as a strong acceptor. Introducing the carbon bridge in the fullerene molecule with two carbon atoms with $s p^{3}$ hybridization can increase the parameter $\varphi_{0}$ and decrease its acceptor strength.

\section{REFERENCES}

1. H. W. Kroto, J. R. Heath, S. C. O'Brien, R. F. Curl, and R. E. Smalley, Nature, 318: 162 (1985).

2. L. W. Tutt and A. Kost, Nature, 356: 225 (1992).

3. G. Orlandi and F. Negri, Photochem. Photobiol. Sci., 1: 289 (2002).

4. C. H. Zhou and X. Zhao, J. Comput. Chem., 33: 861 (2012).

5. C. Deibel and V. Dyakonov, Rep. Prog. Phys., 73: 401 (2010).

6. C. Villegas, E. Krokos, P. A. Bouit, J. L. Delgado, D. M. Guldi, and N. Martin, Energy Environ. Sci., 4: 679 (2011).

7. F. Meng, J. Hua, K. Chen, H. Tian, L. Zuppiroli, and F. Nueesch, J. Mater. Chem., 15: 979 (2005).

8. A. M. Lopez, A. Mateo-Alonso, and M. Prato, J. Mater. Chem., 21: 1305 (2011).

9. $\quad$ E. F. Sheka, Chem. Phys. Lett., 438, Iss. 1-3: 119 (2007); https://doi.org/10.1016/j.cplett.2007.02.053.

10. K. Sen, R. Crespo-Otero, W. Thiel, and M. Barbatti, Comput. Theoret. Chem., 1040-1041: 237 (2014); http://dx.doi.org/10.1016/j.comptc.2014.02.024.

11. A. Streitwiser, Molecular Orbital Theory (New York-London: John Wiley and Sons, Inc.: 1963).

12. M. Frisch, G. Trucks, H. Schlegel et al., Gaussian03; Revision B.05 (Pittsburgh, PA: Gaussian Inc.: 2003).

13. A. D. Kachkovskiy, Russian Chemical Reviews, 66: 647 (1997).

14. N. E. Kornienko, N. P. Kulish, S. A. Alekseev, O. P. Dmitrenko, and E. L. Pavlenko, Opt. Spectrosc., 109: 742 (2010). 